International Journal of Linguistics, Literature and Translation

ISSN: 2617-0299 (Online); ISSN: 2708-0099 (Print)

DOI: $10.32996 /$ ijllt

Journal Homepage: www.al-kindipublisher.com/index.php/ijltt

\title{
Conjunction Shifts and their Impact on Translation Quality of Orwell's Animal Farm
}

\author{
Marcelinus Aris Hardono 18 (D) $\triangle$ Nababan $^{2}$ 8 (D), Riyadi Santosa 3 (D), \\ ${ }^{1}$ Postgraduate Student, Linguistic Program, Sebelas Maret University, Surakarta, Indonesia \\ ${ }^{23}$ Professor, Linguistic Program, Sebelas Maret University, Surakarta, Indonesia \\ $\square$ Corresponding Author: Marcelinus Aris Hardono, E-mail: arisarnijosef@gmail.com
}

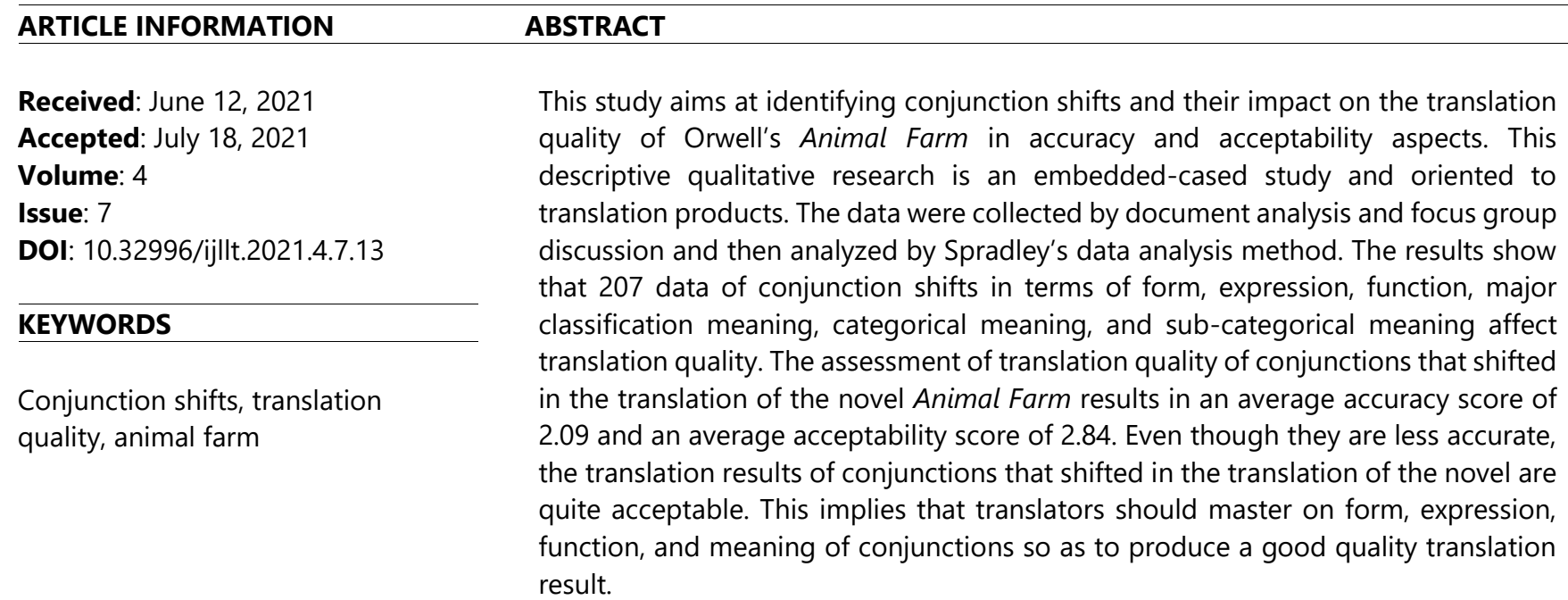

\section{Introduction}

Animal Farm, written by George Orwell, is a phenomenal political allegory novel that satirizes the totalitarianism of the Soviet Union during World War II. It tells a story of events on a farm. The animals who felt oppressed by their master, the owner of the farm, carried out a coup or overthrow of power. The animals then took control of the farm and sent out their master. However, things turned to be worse and they were trapped in a situation they did not imagine.

In order to be enjoyed by readers of different languages, a source text (ST) must be well translated, and to produce a good translation several requirements are needed. Nababan (2006) states that the quality of a translation product will depend on the translation process, and the translator's expertise will very much determine the success of a translation process in carrying out his duty. Before the translating process, the translator must first analyze the ST comprehensively in terms of lexicon/register, genre, style, and target audience. Only then can he properly translate the ST into the target text (TT). This of course will lead to difficulties in translation, especially in finding the equivalence of language units between ST and TT. Such difficulties can be overcome by applying the theories suggested by linguistic experts.

One of the linguistic experts who is also the pioneer of Systemic Functional Linguistics (SFL) theory is Halliday. Halliday et al. (2014) explain that equivalence must be defined according to its meta-function, namely ideational, interpersonal, and textual. Discourse logic resides in an ideational meta-function that expresses experiential and logical meanings. It is expressed through conjunctive relation which connects events, qualities, and ideas in discourse, including between clauses and between groups of clauses, either explicitly or implicitly (Martin et al. in Santosa, 2011). Furthermore, conjunctive relations are classified into three types, namely conjunctions (internal and external), continuatives, and metaphors (logic as process, logic as circumstance, and logic as things).

\section{K C AL-KINDI CENTER \\ $\mathbf{R}$ D FOR RESEARCH AND DEVELOPMENT}

Your gateway to world-class research

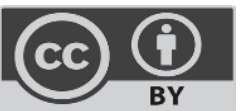

Published by Al-Kindi Center for Research and Development, London, United Kingdom. Copyright (c) the author(s). This open access article is distributed under a Creative Commons Attribution (CC-BY) 4.0 license 
Some previous related studies were conducted by Ulfah (2013) and Wenlin (2019). In her study, Ulfah tried to determine the forms and meanings of conjunctive relation in Smith's The Vampire Diaries: The Awakening, clarify the influences of conjunctive relation toward logical relation based on translation accuracy and acceptability, and clarify the influences of conjunctive relation toward the structure of the narrative text in the novel. Further, Wenlin, in her study, tried to identify the forms and meanings of logical metaphor in the novel Pride and Prejudice, identify the translation techniques in translating logical metaphor, map the shifts in the translation of logical metaphor produced by the application of translation techniques, and explain the relation between translation techniques and the quality of the logical metaphor's translations. Accordingly, this study aims to investigate conjunction shifts and their impact on translation quality.

\section{Literature Review}

\subsection{Systemic Functional Linguistics (SFL)}

According to Halliday in Wiratno et al. (2014), language in terms of SFL is a form of social semiotics that works in the contexts of situation and culture, which are used both spoken and written. In so doing, language carries out three main functions, namely ideational, interpersonal, and textual functions. The ideational meta-function consists of the experiential meta-function, which expresses the meaning or reality of experience, and the logical meta-function, which realizes the logical meaning or logical reality that connects these experiences. In SFL, there is a concept of logic of discourse which, according to Santosa (2011), is a logical reality that connects the realities of experience and is built through the relationship between experiences in a discourse.

Halliday et al. in Santosa (2011) suggests that logic at the discourse level is expressed through conjunctive relation, either explicitly or implicitly. The logic of discourse expresses the relationship between events and qualities or connects and organizes arguments or evidence in a discourse. According to their function or role, conjunctive relations are classified into two types, namely external and internal. The conjunctive relations which connect events and qualities are external whereas those which organize arguments, evidence, and conclusions are internal. In addition, according to their form, conjunctive relations are classified into three types, namely conjunctions, continuatives, and metaphors. In the SFL tradition, the classification of conjunctions is not based on form but on meaning. Martin et al. in Santosa (2011) suggests that in general, conjunctions have four major classification meanings, namely addition, comparison, time, and consequence. Each of the major classification meanings has more detailed sub-classifications. This is presented in the following table.

Table 2.1 Classification of External Conjunctions

\begin{tabular}{|c|c|c|}
\hline & Meaning & \\
\hline Major classification & Categorical & Sub-categorical \\
\hline \multirow[t]{2}{*}{ Addition } & Additive & \\
\hline & Alternative & \\
\hline \multirow{5}{*}{ Comparison } & Similar & Compare \\
\hline & & More than \\
\hline & Different & Opposite \\
\hline & & Excepting \\
\hline & & Replacing \\
\hline \multirow{4}{*}{ Time } & Successive & Sometime \\
\hline & & Immediate \\
\hline & Simultaneous & Near \\
\hline & & Interrupted \\
\hline \multirow{6}{*}{ Consequence } & Expectant & Cause \\
\hline & & Effect \\
\hline & Concessive & \\
\hline & Means & \\
\hline & Purpose & \\
\hline & Condition & \\
\hline
\end{tabular}

Table 2.2 Classification of Internal Conjunctions

\begin{tabular}{lll}
\hline & Meaning & \\
\hline Major classification & Categorical & Sub-categorical \\
\hline Addition & Developing & Additive \\
\cline { 2 - 3 } & & Alternative \\
\cline { 2 - 3 } & Staging & Framing \\
\cline { 2 - 3 } & & Sidetracking \\
\hline & Similar & Rework
\end{tabular}




\begin{tabular}{lll} 
Comparison & & \multicolumn{1}{c}{ Adjust } \\
\cline { 2 - 3 } & \multirow{2}{*}{ Different } & More than \\
\cline { 2 - 3 } & & Oppose \\
\cline { 2 - 3 } & & \multicolumn{1}{c}{ Converse } \\
\hline \multirow{2}{*}{ Time } & Successive & \\
\cline { 2 - 3 } & Simultaneous & Conclude \\
\cline { 2 - 3 } & Concluding & Justify \\
\cline { 2 - 3 } & & Concede \\
\cline { 2 - 3 } & Countering & Unexpected \\
\hline
\end{tabular}

\subsection{Translation Quality Assessment}

Translation results need to have good quality in order to avoid distortion of meaning. The quality of translation results can be assessed by using a translation quality assessment instrument consisting of three criteria, namely accuracy, acceptability, and readability. Each criterion includes three levels. Nababan et al. (2012) describes the instrument for translation quality assessment as follows:

Table 2.3 Translation Accuracy Assessment Instrument

\begin{tabular}{lcl}
\hline $\begin{array}{l}\text { Translation Category } \\
\text { Accurate }\end{array}$ & Score & Qualitative Parameters \\
\hline Less Accurate & $\begin{array}{l}\text { The meanings of words, technical terms, phrases, clauses, sentences, or source language texts } \\
\text { are accurately transferred into the target language; absolutely no meaning distortions occur. }\end{array}$ \\
$\begin{array}{l}\text { Most of the meanings of words, technical terms, phrases, clauses, sentences, or source } \\
\text { language texts had been transferred accurately into the target language. However, there are } \\
\text { still distortions of meaning, translation of double meanings, or the meanings are deleted, } \\
\text { which disturb the integrity of a message. }\end{array}$ \\
$\begin{array}{l}\text { Ine meanings of words, technical terms, phrases, clauses, sentences, or source language texts } \\
\text { are not accurately transferred into the target language or totally deleted. }\end{array}$ \\
\hline
\end{tabular}

Table 2.4 Translation Acceptability Assessment Instrument

\begin{tabular}{lcl}
\hline Translation Category & Score & Qualitative Parameters \\
\hline Acceptable & 3 & $\begin{array}{l}\text { The translations are natural; the technical terms are commonly used and familiar to the reader; } \\
\text { phrases, clauses, and sentences are in accordance with the rules of the Indonesian language. }\end{array}$ \\
\hline Uns Acceptable & 2 & $\begin{array}{l}\text { In general, the translation already feels natural; however, there are few problems in the use of } \\
\text { technical terms or grammatical errors. }\end{array}$ \\
\hline 1 & $\begin{array}{l}\text { The translations are not natural; the technical terms are not commonly used and not familiar } \\
\text { to the readers; phrases, clauses, and sentences are not in accordance with the rules of the } \\
\text { Indonesian language. }\end{array}$ \\
\hline
\end{tabular}

Table 2.5 Translation Readability Assessment Instrument

\begin{tabular}{lll}
\hline Translation Category & Score & Qualitative Parameters \\
\hline Readable & 3 & $\begin{array}{l}\text { The readers can understand the words, technical terms, phrases, clauses, sentences, or } \\
\text { translation texts easily. }\end{array}$ \\
\hline Less readable & 2 & $\begin{array}{l}\text { In general, the readers can understand the translations; however, there are certain parts that } \\
\text { require to be read more than once to understand. }\end{array}$ \\
\hline Unreadable & 1 & The readers cannot understand the translation.
\end{tabular}

The results of the calculation of each level of the scale above show both the amount and the percentage so that the level of accuracy, readability, and acceptability can be obtained. The total score of all the criteria/definitions above will be the final score for the translation quality of a given text.

It should be noted that we cannot assess a translated text as a whole, for example, the translation quality of a full novel. The assessment can be minimized by purposive sampling, for example only pointing out cultural terms, technological terms, certain dictions, certain translation techniques, and so on.

However, in this study, only two criteria were used, namely accuracy and acceptability. The readability criteria were not used because the previous two criteria were considered sufficient to assess the quality of the translation of conjunctions that shifted.

\section{Methodology}


The research used a descriptive qualitative method. According to Gay in Hikmat (2011), a descriptive qualitative method is an activity that includes collecting data in order to test hypotheses. In so doing, the researcher describes what he saw, talked about, and did during the study. The research, thus, integrates the research focus and the context of in-depth understanding. Context is very decisive in determining a finding. Research results have meaning for other contexts. The value structure that appears in the context is decisive about what to look for from research results.

This study used the SFL approach. It is comprehensive, which means language assessment is carried out as a whole. In this case, the assessment of an aspect is always connected to the overall description. In other words, SFL bases its analysis on the text as a whole and not on chunks of text.

According to Sutopo (2002), data sources in a descriptive qualitative method can be in the form of humans and their behavior, events, documents, archives, and other objects. There are two kinds of data sources in the study. The first is in the form of documents, namely the novel Animal Farm by George Orwell (1945) and the Indonesian version of Animal Farm by George Orwell (2015) which was translated by Bakdi Sumanto. The second is in the form of informants or people who understand more about the object of study and are able to explain it to the researcher.

The data were collected by means of three kinds of techniques, namely observation, questionnaire, and interview. Observation is conducted by observing the use of language and recording data relevant to the research objectives (Subroto, 1992). In this study, the researcher observed the novel Animal Farm and its translation and then took notes on the conjunction shifts. The second technique is a questionnaire which is conducted before the researcher entered the field with a more in-depth study (Sutopo, 2002). This questionnaire is open, which means the researcher gives the opportunity to the informant to explain their opinion on the questions asked by the researcher. Information from this questionnaire is then used as a reference in an interview to obtain more in-depth information. The third technique is an interview which was conducted to humans as resource persons or informants to collect information from data sources (Sutopo, 2002). This was conducted only on selected informants. During the interview, the researcher took notes on important things which later be used to draw conclusions.

The collected data were analyzed inductively according to the characteristics of the descriptive qualitative method in which the data were collected one by one to develop a complete theory. The SFL approach used in this study is mainly the theories of conjunctions suggested by Martin et al. (2007) and Santosa (2011).

Furthermore, the stages of data analysis used in this study were Spradley's. According to Spradley (1980), data analysis includes domain, taxonomy, and componential analysis. Domain analysis is an analysis used to determine phenomena to differentiate data from the ones which are not data. Data in the form of conjunction shift in translation from ST to TT were collected from data sources and selected based on the SFL approach. By using taxonomic analysis, all data were classified into groups based on the natural category of the objective reality. Componential analysis is a combination of domain and taxonomy analysis, which connects all domain and taxonomy categories into one matrix. Domains are placed in vertical categories while taxonomies are placed in horizontal ones. Thus, this study investigates conjunction shifts in terms of form, expression, function, and meaning, and then analyzes their impact on translation quality.

\section{Results and Discussion}

\subsection{Conjunction Shifts}

In this study, the types of conjunction are based on the classification of conjunctive relation suggested by Martin et al. (2007) and Santosa (2011). According to their form, conjunctive relations are classified into three types, namely conjunctions, continuatives, and metaphors. Then, according to the expression, conjunctions are classified into two types, namely implicit and explicit. According to their function, conjunctions are classified into two types, namely external and internal. Both external and internal conjunctions have four major classification meanings for each, namely addition, comparison, time, and consequence. Each of these major classification meanings is divided into several categorical meanings, some of which are further divided into sub-categorical meanings. Not all of these types of conjunctions were found in the novel Animal Farm and underwent a shift in translation. There were 207 data of conjunction shifts found in the translation of the novel.

In addition, conjunction shifts can also be viewed in terms of the level of the shift. In this study, conjunction shifts were found at all levels. The most conjunction shifts were in terms of expression, and then of major classification meaning, of form, of categorical meaning, of function, and sub-categorical meaning, respectively. 
Table 4.1 Conjunction Shifts in Term of Level

\begin{tabular}{lll}
\hline \multicolumn{3}{c}{ Conjunction Shifts } \\
\hline Level & Quantity & Percentage \\
\hline Form & 35 & $16.9 \%$ \\
\hline Expression & 106 & $51.2 \%$ \\
\hline Function & 3 & $1.5 \%$ \\
\hline Major classification Meaning & 45 & $21.7 \%$ \\
\hline Categorical Meaning & 15 & $27.2 \%$ \\
\hline Sub-categorical Meaning & 3 & $1.5 \%$ \\
\hline
\end{tabular}

\subsubsection{Conjunction Shifts in Term of Expression}

Two types of conjunctions, according to the expression, are explicit and implicit. Explicit conjunctions are conjunctions that appear as markers of a conjunctive relation while implicit conjunctions are conjunctions that do not appear as markers of a conjunctive relation (Sriyono, 2012). In this study, 106 data or $51.2 \%$ of conjunction shifts in terms of expression were found. They consisted of 66 data from implicit to explicit and 40 data from explicit to implicit. One conjunction shift of this type occurs in the following datum.

ST: $\quad$ The two horses had just lain down when a brood of ducklings, which had lost their mother, filed into the barn, ( $\varnothing$ ) cheeping feebly and wandering from side to side to find someplace where they would not be trodden on.

TT: $\quad$ Kedua kuda itu baru saja berbaring ketika anak itik seperindukan yang telah kehilangan ibunya masuk ke lumbung, sambil menciap lemah dan berputar-putar ke sana kemari mencari tempat aman supaya tidak terinjak-injak.

In the above datum, there is implicit conjunction and it was translated into sambil which is explicit conjunction. Thus, the translation underwent a shift in terms of expression.

\subsubsection{Conjunction Shifts in Term of Major Classification Meaning}

Four types of major classification meaning are addition, comparison, time, and consequence. Shifts of this type occur from conjunctions having a certain major classification meaning into those having another major classification meaning.

In this study, there were 45 data or $21.7 \%$ of conjunction shifts in terms of major classification meaning. They consisted of 6 data of the shifts from addition to comparison meanings, 4 from addition to time, 3 from addition to consequence, 1 from comparison to addition, 2 from time to addition, 3 from consequence to addition, 4 from comparison to time, 1 from time to comparison, 3 from consequence to comparison, 6 from time to consequence, and 2 from consequence to time. One conjunction shift of this type occurs in the following datum.

ST: $\quad$ Alone among the animals on the farm he never laughed. If asked why he would say that he saw nothing to laugh at. TT: Dialah satu-satunya binatang di peternakan itu yang tidak pernah tertawa. Ketika ditanya mengapa tak tertawa, ia akan menjawab tidak ada yang pantas ditertawakan.

In the above datum, there is the word If which is conjunction having a consequence meaning. It was translated into Ketika which is a conjunction having time meaning. Thus, the translation underwent a shift in terms of major classification meaning.

\subsubsection{Conjunction Shifts in Term of Form}

Three types of conjunctive relation, according to their form, are conjunctions, continuatives, and metaphors. Conjunctions are a form of conjunctive relation that realizes the logic of discourse that connects events, qualities, or ideas between clauses and between groups of clauses, continuatives are grammatical units in a clause that appear as a group of verbs, while metaphors are a form of metaphorical conjunctive relation that functions as a certain structure in a sentence (Santosa, 2011). As stated earlier, this study focuses only on conjunctions and not on continuatives and metaphors.

In this study, 35 data or $16.9 \%$ of conjunction shifts in terms of form were found. They consisted of 24 data of shifts from conjunction to a non-conjunction and 11 data from conjunction to a deleted conjunction. One conjunction shift of this type occurs in the following datum.

ST: With one accord, though nothing of the kind had been planned beforehand, they flung themselves upon their tormentors. TT: (\#Meski) tanpa rencana sebelumnya, binatang-binatang itu berbarengan meloncat ke arah para pelecut itu.

In the above datum, there is the word though which is a conjunction. It was translated into (\#Meski) which is not a conjunction. Thus, the translation underwent a shift in terms of form.

\subsubsection{Conjunction Shifts in Term of Categorical Meaning}


As stated earlier, external and internal conjunctions have, for each, four major classification meanings, namely addition, comparison, time, and consequence. However, these major classification meanings have different categories for each type of conjunctions. The external conjunctions have additive and alternative categorical meanings for addition, similar and different categorical meanings for comparison, successive and simultaneous categorical meanings for time, and cause, concessive, means purpose, and condition categorical meanings for consequence. Meanwhile, the internal conjunctions have to develop and staging categorical meanings for addition, similar and different categorical meanings for comparison, successive and simultaneous categorical meanings for time and concluding and countering categorical meanings for consequence.

Conjunction shifts in terms of categorical meaning occur from conjunctions with a certain categorical meaning to those with another. In this study, 15 data or $27.2 \%$ of conjunction shifts in terms of categorical meaning were found. They consisted of 1 shift from purpose to concessive, in consequence, 2 from purpose to cause in consequence, 1 from alternative to additive, in addition, 1 from successive to simultaneous in time, 7 from simultaneous to successive in time, and 3 from similar to different in comparison. One conjunction shift of this type occurs in the following datum.

ST: $\quad$ We are born, we are given just so much food as will keep the breath in our bodies, and those of us who are capable of it are forced to work to the last atom of our strength, and the very instant that our usefulness has come to an end we are slaughtered with hideous cruelty.

TT: $\quad$ Kita lahir, kita diberi begitu banyak makanan, sehingga menjaga napas dalam tubuh kita, dan di antara kita yang mampu dipaksa kerja dengan seluruh kekuatan kita sampai atom terakhir kekuatan kita; dan segera setelah kegunaan kita berakhir, kita disembelih dengan cara yang keji.

In the above datum, there is a pair of conjunctions so...as which is conjunction having purpose meaning in consequence. They were translated into sehingga which was a conjunction having cause meaning in consequence. Thus, the translation underwent a shift in terms of categorical meaning.

\subsubsection{Conjunction Shifts in Term of Sub-categorial Meaning}

As stated earlier, each of the major classification meanings has different categorical meanings for external and internal conjunctions. However, not all of these categorical meanings are divided into sub-categorical meanings. Only some of them have sub-categorical meanings. The external conjunctions include comparing sub-categorical meaning for similar in comparison, opposite, excepting, replacing, and more than sub-categorical meanings for different in comparison, some time and immediate sub-categorical meanings for successive in time, near and interrupted sub-categorical meanings for simultaneous in time while internal conjunctions include additive and alternative sub-categorical meanings for developing in addition, framing and sidetracking sub-categorical meanings for staging in addition, compare, rework, and adjust sub-categorical meanings for similar in comparison, more than, oppose and converse sub-categorical meanings for different in comparison, conclude and justify subcategorical meanings for concluding in consequence, concede and unexpected sub-categorical meanings for countering in consequence.

Conjunction shifts in terms of sub-categorical meaning occur from conjunctions having a certain sub-categorical meaning to those having another sub-categorical meaning. In this study, 3 data or $1.5 \%$ of conjunction shifts in terms of sub-categorical meaning were found. They consisted of 2 shifts from immediate to some time of successive in time and 1 shift from excepting to opposite of different in comparison. One conjunction shift of this type occurs in the following datum.

ST: It had been agreed that they should all meet in the big barn as soon as Mr. Jones was safely out of the way.

TT: $\quad$ Sudah disepakati bahwa mereka akan bertemu di lumbung besar setelah Pak Jones benar-benar meninggalkan tempat itu.

In the above datum, there is a phrase as soon as which is conjunction having an immediate meaning of successive in time. It was translated into setelah which is conjunction having the sometime meaning of successive in time. Thus, the translation underwent a shift in terms of sub-categorical meaning.

\subsubsection{Conjunction Shifts in Term of Function}

Two types of conjunctions, according to their function, are external and internal. External conjunctions connect events and qualities in the reality of experience while internal conjunctions organize arguments, evidence, or draw conclusions in a discourse (Santosa, 2011). Conjunction shifts in terms of function occur from external to internal conjunctions or vice versa. However, in this study, only 3 data or $1.5 \%$ of conjunction shifts in terms of function were found. All these shifts were from external to internal conjunctions while shifts from internal to external conjunctions were not found. One conjunction shift of this type occurs in the following datum. 
ST: $\quad$ This work was strictly voluntary, but any animal who absented himself from it would have his rations reduced by half. Even so, it was found necessary to leave certain tasks undone.

TT: Kerja ini benar-benar sukarela, tetapi binatang siapa saja yang tidak hadir, ransumnya juga akan dikurangi setengah. Meskipun demikian, ternyata perlu meninggalkan beberapa tugas yang belum selesai.

In the above datum, there is a phrase Even so which is external conjunction. It was translated into Meskipun demikian which is internal conjunction. Thus, the translation underwent a shift in terms of function.

\subsection{Translation Quality}

The next finding is about the translation quality of conjunctions that shifted in the translation of the novel Animal Farm. In this study, the translation quality of conjunctions was analyzed in two aspects, namely accuracy, and acceptability.

\subsubsection{Accuracy}

Accuracy is closely related to the equivalence of meaning between SL and TL. To determine the accuracy of the translation results, the translation accuracy assessment instrument is used. The instrument was adapted from Nababan, et al. (2012). Conjunction translation results are considered to be:

(1) accurate when the form, function, and meaning of the conjunctions in SL are accurately transferred into SL. In this case, it is possible that there is a shift in terms of expression, either from implicit to explicit conjunctions or vice versa, but as long as there is no shift in terms of form, function, and meaning, the conjunction translation results are still considered to be accurate.

(2) less accurate when the form, function, and meaning of conjunctions in SL are accurately transferred into SL but there is a slight distortion of meaning, namely a shift in terms of categorical or sub-categorical meaning. In this case, there is no shift in terms of form, function, and major classification meaning in the translation results.

(3) inaccurate when the form, function, or meaning of conjunctions in SL are inaccurately transferred into SL. The conjunction shift can occur in terms of form, function, or major classification meaning in the translation results.

The results of conjunction that shifted in the translation of the novel Animal Farm show that there are three categories of accuracy, namely accurate translation including 104 data or $50.2 \%$, less accurate translation including 17 data or $8.2 \%$, and inaccurate translation including 86 data or $41.6 \%$.

\subsubsection{Accurate}

It was found that 104 or $50.2 \%$ out of 207 data of conjunctions that shifted were translated accurately. Of these 104 data, it turns out that all of them shifted only in terms of expression, namely from explicit to implicit conjunctions or vice versa. None of the translation results shifted in terms of form, function, or meaning. One of these is the following datum:

ST: I have had a long life, I have had much time for thought as I lay alone in my stall, and I think I may say that I understand the nature of life on this earth as well as any animal now living. ( $\varnothing$ ) It is about this that I wish to speak to you

TT: Saya sudah hidup lama, saya sudah berkesempatan berpikir dan merenung tatkala saya sendirian di kandang saya. Dan, saya pikir saya bisa berkata bahwa saya mengerti sifat kehidupan di bumi maupun setiap binatang yang hidup. Nah, tentang masalah inilah yang ingin saya sampaikan pada kalian.

In the above datum, at the beginning of the second sentence for exactly, there is internal implicit conjunction having concluded meaning of concluding in consequence, symbolized ( $)$. It was translated into Nah which is internal explicit conjunction having conclude meaning of concluding in consequence. Thus, the translation underwent a shift only in terms of expression, while the form, function, and meanings of major classification, categorical, and sub-categorical did not undergo a shift and was considered to be accurate.

\subsubsection{Less Accurate}

It was found that 17 or $8.2 \%$ out of 207 data of conjunctions that shifted were translated less accurately. Of these 17 data, it turns out that all of them underwent a shift only in terms of categorical or sub-categorical meanings. None of the translation results underwent a shift in terms of form, expression, function, or major classification meaning. One of the less accurate translation results occurs in the following datum:

ST: $\quad$ 2. Whatever goes upon four legs, or has wings, is a friend.

TT: 2. Apa pun yang berjalan dengan empat kaki dan bersayap adalah teman. 
In the above datum, there is the word or which is external conjunction having an alternative meaning in addition. It was translated into dan which is external conjunction having additive meaning in addition. Thus, the translation underwent a shift only in terms of categorical meaning, while the form, expression, function, and major classification meaning did not undergo a shift and was considered to be less accurate.

\subsubsection{Inaccurate}

It was found that 86 or $41.6 \%$ out of the 207 data of conjunction that shifted were translated less accurately. Of these 86 data, it turned out that all of them underwent a shift in terms of form or meaning. All of these translations also underwent a shift in terms of expression or function, but what caused the translation to be inaccurate was only the shift in terms of form or major classification meaning. One of these is the following datum:

ST: He did his work in the same slow obstinate way as he had done it in Jones's time, never shirking and never volunteering for extra work either.

TT: la bekerja dengan sama lambannya (\#seperti) pada masa Pak Jones. la tidak pernah meringkik sebagaimana laiknya seekor keledai, juga tak pernah bekerja ekstra secara sukarela.

In the above datum, there is the word as which is external conjunction having a similar meaning in comparison. It was translated into (\#seperti) which is not a conjunction. Thus, the translation underwent a shift in terms of form and was considered to be inaccurate.

\subsubsection{Acceptability}

Acceptability is closely related to the naturalness of the translation to the rules and norms of the TL culture. To determine the acceptability of the translation results, the translation acceptability assessment instrument is used. The instrument was adapted from Nababan, et al. (2012). Conjunction translation results are considered to be:

(1) acceptable when it feels natural. In other words, the translation of the conjunction is a common and familiar thing for readers and is in accordance with Indonesian language rules.

(2) less acceptable when it feels natural but there is a meaning of conjunction in SL that is not conveyed.

(3) unacceptable when the translation of the conjunction feels unnatural or not commonly used by the reader, even sometimes the conjunction in SL is omitted in TL so that it is not natural and unclear.

The translation results of conjunctions in the novel Animal Farm were found in three categories of acceptability, namely 187 or $90.3 \%$ data of acceptable translations, 7 or $3.4 \%$ data of less acceptable, and 13 or $6.3 \%$ data of unacceptable.

\subsubsection{Acceptable}

It was found that most conjunctions that shifted in the translation of the novel Animal Farm, which is 187 data or $90.3 \%$, are translated acceptable. One of these is the following datum:

ST: On Sundays, there was no work. Breakfast was an hour later than usual, and after breakfast, there was a ceremony that was observed every week without fail. First came the hoisting of the flag.

TT: Pada Minggu, tak ada pekerjaan. Sarapan mundur satu jam daripada biasanya, dan sesudah sarapan ada satu upacara yang selalu dipatuhi. (\#Acara pertama) adalah pengibaran bendera.

In the above datum, there is the word First which is a conjunction. It was translated into (\#Acara Pertama) which is not a conjunction. Although there is a shift in terms of form, the phrase (\#Acara Pertama) is a common thing for readers and is in accordance with Indonesian language rules so that this translation was considered to be acceptable.

\subsubsection{Less Acceptable}

It was found that only a few conjunctions, which were 7 data or $3.4 \%$, that shifted in the translation of the novel were translated less acceptable. One of these is the following datum:

ST: $\quad$ Then the sheep broke out into a tremendous bleating of "Four legs good, two legs bad!" which went on for nearly a quarter of an hour and put an end to any chance of discussion.

Afterward, Squealer was sent round the farm to explain the new arrangement to the others.

TT: Kemudian, si biri- biri mulai mengembik keras "Kaki empat baik, kaki dua jahat" yang berlangsung selama hampir seperempat jam dan mengakhiri setiap kesempatan diskusi.

(\#Kelak) Squealer disuruh berkeliling peternakan untuk menjelaskan pengaturan baru itu pada yang lainnya. 
In the above datum, there is the word Afterward which is a conjunction. It was translated into (\#Kelak) which is not a conjunction. The translation result is less acceptable because even though it feels natural, it is not the equivalent of the conjunctions in SL. The word (\#kelak) has a different meaning from Afterward so that this translation was considered to be less acceptable.

\subsubsection{Unacceptable}

It was found that not many conjunctions, which were 13 data or $6.3 \%$, that shifted in the translation of the novel were translated unacceptably. One of these is the following datum:

ST: The animals had assumed as a matter of course that these would be shared out equally; one day, however, the order went forth that all the windfalls were to be collected and brought to the harness-room for the use of the pigs.

TT: $\quad$ Para binatang menduga bahwa buah-buahan itu akan dibagi dengan adil; tetapi, pada suatu hari ada pengumuman bahwa buah-buahan yang jatuh ke tanah itu $(\varnothing)$ akan dibawa ke ruang penyimpanan perlengkapan untuk dikonsumsi oleh babi-babi.

In the above datum, there is the word and which is a conjunction. In this case, the conjunction in SL has additive meaning in addition but was omitted in TL by the translator and not translated. In this way, it caused the loss of logical relation in the SL so that this translation was considered to be unacceptable.

\subsection{The Impact of Conjunction Shifts on Translation Quality}

The shifts that occur in the translation of conjunctions in the novel Animal Farm affect the translation quality. However, only the accuracy and acceptability aspects were analyzed in this study. By observing the translation quality, the impact of conjunction shifts will be seen. This is presented in the following table.

Table 4.2 The Impact of Conjunction Shifts on Translation Quality

\begin{tabular}{|c|c|c|c|c|c|c|}
\hline \multirow[t]{3}{*}{ CONJUNCTION SHIFTS } & \multicolumn{6}{|c|}{ TRANSLATION QUALITY } \\
\hline & \multicolumn{3}{|c|}{ Accuracy } & \multicolumn{3}{|c|}{ Acceptability } \\
\hline & 3 & 2 & 1 & 3 & 2 & 1 \\
\hline Form & & & 35 & 22 & 1 & 12 \\
\hline Expression & 104 & & 2 & 105 & 1 & \\
\hline Function & & & 3 & 3 & & \\
\hline Major Classification Meaning & & & 45 & 39 & 5 & 1 \\
\hline Categorical Meaning & & 14 & 1 & 15 & & \\
\hline Sub-categorical Meaning & & 3 & & 3 & & \\
\hline
\end{tabular}

It was found that there were 35 data of conjunction shifts in terms of form, all of which or $100 \%$ had a low accuracy score or inaccurate, 22 or $62.9 \%$ out of 35 data had a high acceptability score or acceptable, 1 datum or $2.8 \%$ had a moderate acceptability score or less acceptable, and 12 data or $34.3 \%$ had a low acceptability score or unacceptable. Second, there were 106 data of conjunction shifts in terms of expression. 104 data or $98.1 \%$ had a high accuracy score or accuracy and 2 data or $1.9 \%$ had a low accuracy score or inaccurate. Of 106 data, 105 or $99 \%$ had a high acceptability score or acceptable and 1 or $1 \%$ had a moderate acceptability score or less acceptable. Third, there are 3 data of conjunction shifts in terms of function, all of which or $100 \%$ had a low accuracy score or inaccurate but high acceptability score or acceptable. Fourth, there were 45 data of conjunction shifts in terms of major classification meaning, all of which or $100 \%$ had a low accuracy score or inaccurate. Of the 45 data, 39 data or $86.7 \%$ had a high acceptability score or acceptable, 5 data or $11.1 \%$ had a moderate acceptability score or less acceptable and 1 datum or $2.2 \%$ had a low acceptability score or unacceptable. Fifth, there were 15 data of conjunction shifts in terms of categorical meaning, of which 14 data or $93.3 \%$ had a moderate accuracy score or less accurate and 1 datum or $6.7 \%$ had a low accuracy score or inaccurate. All of 5 data or $100 \%$ had a high acceptability score or acceptable. And lastly, there were 3 data of conjunction shifts in terms of sub-categorical meaning, all of which or $100 \%$ had a moderate accuracy score or less accurate and a high acceptability score or acceptable.

In addition, a trend pattern of the impact of conjunction shifts on the accuracy and acceptability of the translation results was also found. First, conjunction shifts in terms of form tend to result in translations with a low accuracy but high acceptability scores. Second, conjunction shifts in terms of expression tend to result in translations with high accuracy and high acceptability scores. Third, conjunction shifts in terms of function tend to result in translations with a low accuracy but high acceptability scores. Fourth, conjunction shifts in terms of major classifications meaning tend to result in translations with a low accuracy but high acceptability scores. Fifth, conjunction shifts in terms of categorical meaning tend to result in translations with moderate accuracy but high acceptability scores. Finally, conjunction shifts in terms of sub-categorical meaning tend to result in translations with moderate accuracy but high acceptability scores. 


\section{Conclusion}

There are 207 data of conjunction shifts found in the translation of the novel Animal Farm. They occurred at all levels, namely form, expression, function, major classification meaning, categorical meaning, and sub-categorical meaning. First, conjunction shifts in terms of form tend to result in inaccurate but acceptable translations. Second, conjunction shifts in terms of expression tend to result in accurate and acceptable translations. Third, conjunction shifts in terms of function tend to result in inaccurate but acceptable translations. Fourth, conjunction shifts in terms of major classification meaning tend to result in inaccurate but acceptable translations. Fifth, conjunction shifts in terms of categorical meaning tend to result in less accurate but acceptable translations. Finally, conjunction shifts in terms of sub-categorical meaning tend to result in less accurate but acceptable translations.

The assessment of translation quality of conjunctions that shifted in the translation of the novel Animal Farm results in an average accuracy score of 2.09 and an average acceptability score of 2.84. This accuracy is moderate or relatively less accurate because the data in this study are only conjunctions that shifted; and not all conjunctions. Thus, it is reasonable if it is not high. On the other hand, the average acceptability score is quite high. Even though they are less accurate, the translation of conjunctions that shifted in the translation of the novel is quite acceptable.

Based on the findings of this study, the researcher has suggestions for professional translators and students majoring in translation studies as well as for researchers in the field of Translation Studies. Professional translators and students majoring in translation studies need to be careful in translating conjunctions. A deep understanding of the form, expression, function, and meaning of conjunctions needs to be mastered so that they can produce a good translation when translating conjunction. If there is a conjunction shift, it is not a shift that causes significant distortion of meaning.

Apart from that, conjunctive relation is a very interesting topic to investigate and conjunctions are only one of the three forms of conjunctive relation. Therefore, the researcher suggests further in-depth research on two other forms of conjunctive relation, namely continuatives and metaphors, especially on their impact on translation quality.

Funding: This research received no external funding

Acknowledgments: This paper is part of my Master's thesis. I wish to thank my two supervisors Prof. Drs. M. R. Nababan, M.Ed, M.A, Ph.D., and Prof. Drs. Riyadi Santosa, M.Ed., Ph.D., for their support and guidance throughout the entire research and writing process.

Conflicts of Interest: The authors declare no conflict of interest.

\section{References}

[1] Halliday, M.A.K. \& Matthiessen, C.M.I.M. (2014). Introduction to Functional Grammar (fourth edition). London dan New York: Routledge

[2] Hikmat, M.M. (2011). Metode Penelitian dalam Perspektif Ilmu Komunikasi dan Sastra. Yogyakarta: Graha IImu

[3] Larson, M.L. (1984). Meaning-Based Translation: A Guide to Cross-Language Equivalence. New York: University Press of America

[4] Martin, J. R. \& Rose, D. (2007). Working with Discourse Meaning Beyond The Clause. London: Continuum

[5] Molina, L. \& Albir, H.A. (2002). Translation Techniques Revisited: A Dynamic and Functional Approach. Meta, 48(4)

[6] Nababan, M.R. (2006). Kecenderungan Baru dalam Studi Penerjemahan. Englonesian, Jurnal Ilmiah Linguistik dan Sastra 2(1), 68-73

[7] Nababan, M.R., Nuraeni, A., \& Sumardiono. (2012). Pengembangan Model Penilaian Kualitas Terjemahan. Kajian Linguistik dan Sastra, 24(1), 39-57

[8] Orwell, G. (1945). Animal Farm. London: Secker and Warburg

[9] Orwell, G. (2015). Animal Farm, translated by Bakdi Soemanto. Yogyakarta: PT Bentang Pustaka

[10] Santosa, R. (2011). Logika Wacana, Analisis Hubungan Konjungtif dengan Pendekatan Linguistik Sistemik Fungsional. Surakarta: UNS Press

[11] Spradley, J.P. (1980). Participant Observasion. New York: Holt, Rinehart and Winston

[12] Sriyono. (2012). Hubungan Konjungtif dalam Penerjemahan. Prosodi, Jurnal Ilmu Bahasa dan Sastra, 6(2)

[13] Subroto. (1992). Metode Penelitian Kualitatif. Surakarta: Universitas Sebelas Maret.

[14] Sutopo, H.B. (2002). Metodologi Penelitian Kualitatif, Dasar Teori dan Terapannya dalam Penelitian. Surakarta: UNS Press

[15] Ulfah, Y.F. (2013). Pergeseran Hubungan Konjungtif dan Dampaknya terhadap Kualitas Terjemahan dalam Novel Bergenre Naratif "The Vampire Diaries: The Awakening": a thesis. Surakarta: Universitas Sebelas Maret.

[16] Wenlin, L. (2019). Analisis Terjemahan Metafora Logika sebagai Hubungan Konjungtif dalam Dua Versi Bahasa Indonesia 